\title{
Den tredje som vej \\ I dialog med den nye kontrarevolution
}

\author{
Af Henning Eichberg
}

Den danske idrætskultur lever i den bedste af de mulige verdener, under den industrielle kapitalismes glade vilkår. En hårdtarbejdende befolkning i en vis homogen livsstilskultur dyrker organiseret idræt, og de arbejdsløse klapper taktfast i deres hænder. Danmarks idræt er moderne ved, at vindere møder vindere gennem universelle regler, eller rettere sagt - hvis man holder øje med flertallet - tabere møder tabere og har det godt. DIF repræsenterer idrætsdisciplinernes særlige kultur, og det kan vi være taknemlige for - især som forskere, når vi bliver bedt om at medvirke ved en reklamefolder eller et politikkatalog. Der mangler kun ét: Idrætten må vedkende sig selv imod alle »revolutionære «, romantiske, grønne og »tredje « fristelser. Vi har det ufatteligt godt. Vi er radikalt moderne, og efter os er der ingen historie længere at forvente.

Det er bemærkelsesværdigt at se kulturkampen imod »Idrættens tredje vej« løfte sig til denne slags politiske pointer. Søren Damkjær vender sig imod det, han læser som en »revolutionsteori«, og slår implicit fast, hvad alternativet burde være: En glad ny kontrarevolution.

Denne modsætning kunne man godt lade blive stående, hvor den er, og overlade den til læseren - som et spejlbillede af det samfundsmæssige tovtrækkeri mellem kritik og nykonservativ kulturkamp. Men det ville være synd at standse her. Thi Søren Damkjærs betragtninger om »Idrættens tredje vej« berører det mere dybtgående, som den nyere idrætsdebat mestensdels er gået hen over. Her står rigtigt nok mere på spil end DIF's og DGI's bekymringer for en omlægning af den offentlige finansiering af idrætten, nemlig grundlæggende kulturelle, politiske og filosofiske holdninger. Det lykkes heldigvis ikke polemikken at fordunkle denne gevinst. Ganske vist: Polemik kan en gang imellem give nyttige (skønt overgearede) henvisninger - som Søren Damkjærs karakterisering af »Idrættens tredje vej« i Dansk sociologi: At bogen forener »den grundtvigianske romantiske bornerthed, den kulturradikale formynderholdning og den socialdemokratiske opdrager-fanatisme«. Polemik kan også være inspirerende, hvor den er poetisk som da han i Idratsliv skabte en tankeforbindelse mellem »det trialektiske troldspejl«, »Snedronningens iskolde palads« og den tredje vej som »et varmt og kropsligt fantasifoster «. Og alligevel: Her drejer det sig om mere end polemik.

Hvad drejer det sig om konkret?

\section{Bort fra den reduktionistiske totonkning}

En væsentlig kerne i debatten er trialektikken. Søren Damkjær har ret $\mathrm{i}$ at påpege dette. Men så konkluderer han, at »trialektikken, det at der altid optræder tre størrelser, åbenbart er et ontologisk princip, dvs. et princip om det værendes natur.« Det er 
en grundlæggende misforståelse af erkendelsesteoretisk art.

At tænke det tredje er en metode. Trialektikken er en analysemetode, lige som dialektikken engang har været det - eller skulle have været, på trods af at den blev ontologiseret af Friedrich Engels og forskellige efterfølgende samfundsfilosoffer. Som metode er trialektikken en måde at analysere på, altså en måde at stille spørgsmål på.

Meget forenklet kan den trialektiske erkendelsesdynamik sammenfattes i et - cirkulært? spiralsk? - flertrinsforløb.

Første trin: Der er sammenhaeng i menneskets og samfundets liv. I denne forstand - og kun i denne, ikke som et system - er der helhed.

Andet trin: Sammenhængen virker kaotisk, og helheden er faktisk uoverskuelig, men vi kan stille nogle pejlemærker op ved at fokusere på modsatninger. Livet er nemlig fuld af indre modsigelser. Og netop modsigelserne fortæller os levende om, hvad der foregår.

Tredje trin: Blandt modsigelsernes levende mangfoldighed er der nogle, som et givet samfund vil betragte som mere væsentlige end andre. I kulturen er der når det kommer til stykket - hegemoni. D.v.s. der træder tit en hovedmodsatning frem, som danner en overordnet konfiguration.

Så langt var også dialektikken gået, således som den var blevet udviklet af filosofien i det 19. århundrede. Men fra konfigurationen »tese vs. antitese « var det altfor fristende at falde tilbage til en dual reduktionisme: Find hovedmodsigelsen - find fjenden! Der var ikke noget tredje, som nødvendigt skulle tænkes med. Heller ikke syntesen var, som Søren Damkjær mener, dette tredje, men den var et resultat af hovedmodsigelsen. Syntesen var ikke noget, som fra sidelinien stillede spørgsmål ved selve dualismen.

Fjerde trin: Hvis tænkningen forbliver hængende ved samfundets hegemoniale dualisme - dette har ikke mindst dialektikkens reale historie gennem det tyvende århundrede vist - så havner man i en ejendommelig stagnation. Mangfoldigheden bliver reduceret til et enten-eller, og det intellektuelle liv indgår i jagten på »fjenden «, hvem det så måtte være. Det intellektuelle liv stagnerer der, hvor kulturen og magten - $\mathrm{i}$ forvejen har etableret de hegemoniale markeringer om godt og ondt. Men der er liv uden for hovedmodsætningen. Det er her, at det tredje får betydning.

Man kan nemlig altid finde noget tredje udenfor det, som vi betragter som den væsentlige kulturelle brudlinie. Det paradoksale er, at perspektivet ud fra dette tredje åbner et nyt syn også på selve det hegemoniale væsentlighedskriterium. Hovedmodsætningen får dybdeskarphed - og den har vi behov for, fordi alle hovedmodsigelser er dømt til historie, dvs. til forandring eller forsvinden. Intellektuelt arbejde har som en væsentlig opgave at løsne jorden for denne forandringsproces. Derfor må det være overskridende. Det gælder om at tænke videre end den bestående normalitet.

Dernæst følger endnu et trin: Også et »tredje alternativ « kan etablere sig som hegemonial og blive til et system. Det har man oplevet gentagne gange i historien. Så kommer øjeblikket, da den trialektiske perspektivforskydning skal anvendes på ny. Og så igen og igen ... (Altså ikke noget talspilleri om Det Fjerde eller Det Femte, som Søren Damkjær ironisk har argumenteret med.)

Trialektikken er altså en metode til at opsøge problemstillinger med, ikke en systemisk triangulering af samfundet. Det er vejen, det gælder. 


\section{Idratsanalysens vej}

Overvejelserne om det tredje er ikke så abstrakte og indskrænket til det filosofiske, som det måske lyder. De har ganske vist vægtige filosofisk-poetiske traditioner med sig - Grundtvigs antropologi om legeme, ånd og selv, Martin Bubers dialogiske princip om jeg'et, det'et og du'et, Asger Jorns »triolektik « ... Men en søgen efter det tredje fører til meget praktiske nyorienteringer på det empiriske felt, i forståelsen af det konkrete samfundsmæssige liv. Idrætten er et levende eksempel.

Første trin: Der er sammenhæng i livet, og derfor er idrætten ikke et isoleret felt $\mathrm{i}$ samfundsorganisationen, ikke kun en »sektor « som nogle konservative teoretikere forud for den nyere sportskritik har antaget. Idræt er et levende udtryk og en poetisk indikator for menneskets socialitet og kropslighed. Idræt og sport betyder, at mennesker mødes i kropslige aktiviteter, det være i fest, konkurrence eller showbiz ...

Andet trin: Idrætten selv og dens sammenhæng med folkelivet fattes bedst ved at betragte dens indbyggede modsætninger nærmere. Der er modsætninger

- mellem gymnastik og sport,

- mellem amatørsport og professionel sport,

- mellem tabere og vindere,

- mellem aktividræt og tilskuersport,

- mellem idræt og sport,

- mellem kvindeidræt og mandeidræt,

- mellem idrætten i Øst og i Vest,

- mellem idræt og kultur,

- mellem staten og organisationerne,

- mellem forening og skole,

- mellem DIF-idræt og DGI-idræt,

- mellem foreningsidræt og kommerciel idræt,

- mellem sport som produktion og sport som reproduktion ...
Der går brudlinier på kryds og tvcers, og nogle modsætninger overlapper hinanden, mens andre ligger på helt forskellige planer. Deres helhed bidrager til en bedre forståelse af samfundslivets mangfoldighed og kropslighed.

Tredje trin: Hvad med hegemonien? I 1980'erne var det ikke så vanskeligt at finde frem til en hovedmodsætning, som samfundet selv betragtede som mere relevant end andre til beskrivelse af idrættens verden: Dualiteten mellem elite og bredde. Den danske kulturpolitik iværksatte derfor udredningen af først en eliteidrætsbetænkning (1983) og så en breddeidrætsbetænkning (1987). Dermed - og med de tilsvarende lovmæssige tiltag - var det slået fast, langs hvilken hovedbrudlinie idrætten var blevet etableret som samfundsmæssig institution - elite vs. bredde.

Fjerde trin: Hvis idrætsforskningen gnidningsløst indgår i denne hoveddiskurs, så kan den godt falde til ro - med svingende projekttilskud fra Team Danmark, med skulderklap fra DIF's breddeudvalg samt måske ovenikøbet med en eller anden universitetsstilling mod slutningen af dette årtusinde. Man kan producere de forudsigelige studier om unge i breddeidrætten og unge i eliten, om kvinder i breddeidrætten og kvinder i eliten, om ældre i breddeidrætten, om breddeidrættens gavnlighed for indvandrere og handicappede, om skader i breddeidrætten og skader i eliten ... og så konkludere de forudsigelige anbefalinger om støtte, som den organiserede idræt i forvejen har formuleret.

Eller forskningen kan træde et stykke udenfor - som »Idrættens tredje vej« forsøgte - og spørge: Er der intet idrætsliv ved siden af eliten og bredden? - Derved bliver man nemlig opmærksom på en empirisk størrelse, som hverken er breddeidræt eller elitesport og alligevel spiller en 
væsentlig rolle for idrættens identitet herhjemme: Det der kaldes den folkelige idraet. Det er i forhold til dette tredje fænomen, at man i Danmark taler om folkelig oplysning - et ord, som hverken den olympiske elitesport eller breddens »idræt for alle « har et forhold til.

Tager man denne tredje position som analytisk indfaldsvinkel - altså ikke affirmativt, ikke som en slags DGI-ideologi så bliver også den hegemoniale modsætning klarere og sat i relief. Hvad er logikken i den hegemoniale modsætning, som på overfladen beskrives som elite vs. bredde? - Præstationssporten (vinder/taber-kode, produktion af resultater) står over for sundhedsidrætten (fitness, reproduktion) og den folkelige netværksidræt som noget tredje gør det synligt. Aksen mellem produktion og reproduktion er den dominerende konfiguration. Eller på iscenesættelsens plan: Turneringen som produktionsshow står overfor selviscenesættelsen i fitnessidrætten - og så er der mødet og kropserfaringen og festen i den folkelige stævneidræt.

Men, som sagt, denne hovedspænding udelukker ikke andre modsætningsforhold. »Idrættens tredje vej« tematiserer ved siden af dette også flere andre spændingsforhold. Især spændingen mellem stat, marked og det civile samfund. Det kan godt være, at det modsvarende modsætningsforhold mellem offentlig socialidræt, kommerciel idræt (inklusive mediesport og sponsorering) og den frivillige forening $i$ fremtiden kommer til at overskygge de hidtidige opdelinger som elite/bredde. På et andet plan ligger de tre scenarier om det effektive samfund (med præstationssporten som ritual), konsensussamfundet (med velfærdsidrætten) og det decentrale samfund (med græsrodsidrætten). På trods af visse overlapninger fører den filosofiske tilgang atter i en anden retning: Man kan med Martin Buber - stille »det-idrætten« (centimeter, gram, sekunder) og »jegidrætten « (min krop, min fitness, min terapi) over for hinanden - og så er der »duidrætten« (fællesskab, udveksling, fest) som et tredje. Endnu en pointe ligger i, hvad der på idrætsdebattens overflade vakte den største irritation i organisationsverdenen: Forslaget om en tredje instans ved siden af det offentlige og organisationerne - en »tredje instans« på en armslængdes afstand $\mathrm{i}$ begge retninger og med kulturpolitisk ansvar for idrætten.

Dernæst følger endnu et trin: Man kan levende forestille sig, at en tredje instans bliver etableret som et Statens Idrætsråd med det resultat at den pludselig er besat af organisationsrepræsentanter og således fungerer som en del af netop det etablerede system, som den skulle have været modspil til. Noget lignende har man oplevet med Team Danmark, som engang var planlagt som en tredje instans med en vis selvstændighed ved siden af Kulturministeriet og DIF hhv. specialforbundene. Men faktisk udviklede Team Danmark sig til en del af DIF-systemet, således at Team Danmarks direktør i al åbenhjertighed kan foreslå officielt at fusionere Team Danmark med DIF (Idrætsliv 1/95). Eliteidrættens offentligt finansierede, »autonome« selvorganisering skal altså slås sammen med en - privat - interesseorganisation. Så galt kan det gå - og så megen kritisk opmærksomhed er nødvendig. Derfor bliver man aldrig færdig med at tænke det tredje.

\section{En konservativ kulturkamps nye dikotomier}

Det er på denne baggrund, at »Idrættens tredje vej« bærer »vejen« i overskriften. Bogen hedder ikke »Idrættens tredje sy- 
stem « og har intet ontologisk sigte. Den udgør en analysemetode og ikke noget systembyggeri.

Hvor nødvendig denne vej er, viser netop Søren Damkjærs afvisning, som bekræfter trialektikkens kritiske potentialer. Her stødes man nemlig eksplicit tilbage til en tænkning af ufrugtbare dualismer. Først roses de etablerede dikotomier som subjekt vs. objekt, herre vs. slave etc. Og så overføres totænkningen til nye dualismer i en konservativ kulturkamp imod »den tredje vej «:

- idrættens banalitet vs. kropserfaringens idealisme,

- vind/tab-kode vs. kropslighed,

- det-regler vs. du-kroppen,

- modernisme vs. »romantisk revolutionsforventning «,

- udviklingen vs. tilbagevenden,

- industrisamfundets forsvar vs. kulturkritikken,

- virkelighed vs. utopi,

- idrættens affirmation vs. sportskritikken

I baggrunden står altid den gamle vesterlandske bedreviden: Det rigtige vs. det forkerte.

Hvor den kritiske sociologi distanceret prøver at belyse idrættens placering i samfundet med så mange facetter som muligt, der ser man ud fra et konservativt kulturkampsperspektiv industrisamfundet erklæret som »hovedfjende « og idrætten »fordømt « eller lagt for »had «. Det viser en principiel misforståelse af, hvad kritik i grunden er. Kritik er et arbejde med virkelighedens indbyggede modsigelser. Kritik er dermed fundamentalt forskellig fra had, fordømmelse eller fjendskab. Kritik er erkendelsens vej. Søren Damkjær læser derimod sin egen hhv. en konservativ kulturkamps dualisme ind i den netop mere diffe- rentierede - og derfor trialektiske - kritiske teori.

Denne dualisme træder også frem i en evolutionistisk form, gennem brugen af et problematisk udviklingsbegreb. »Udviklingen « - eller det man tidligere mere naivt har kaldt »fremskridtet«, og som systemteorien nu idag kalder »moderniseringen - lægger et éndimensionalt bevægelsesmønster over historien: Alt, som opstår alternativt, ønsker kun at $»$ vende tilbage til de ikke- og før-europæiske kulturer «. For eksempel da folkebevægelser i 1970'erne sagde »Atomkraft - nej tak«, var atomindustriens svar »Steinzeit - nein danke«. Idag er vi klogere og ved fra dansk erfaring, at dikotomien mellem atomkraft og stenalder ikke slår til, men at der findes yderligere energipolitiske valgmuligheder. Alligevel kan man genkende logikken af »Stenalder - nej tak «nu igen i Søren Damkjærs argumentation, men den har ikke hold i bogen »Idrættens tredje vej«, som konsekvent bruger historie som historie og ikke som utopi. Søren Damkjærs advarsel imod en romantisk »tilbagevenden« er et fantasifoster af den dualistiske evolutionstænkning, som ikke kan forestille sig udviklinger eller moderniseringer i flertal, altså forandringer som peger i forskellige retninger i en åben fremtid. Derfor er scenarier - som i »Idrættens tredje vej « - en mere passende metode til at tænke fremtiden end »udviklingen« i ental.

\section{En revolutionoer teori?}

Her kan vi vende tilbage til konservatismens yndlingsdikotomi: Kontrarevolution vs. revolution. Det generer åbenbart, at vores egen tid forsyner os med et levende eksempel på, at idrætten lige som samfundet - og samfundet lige som idrætten - nogle gange bevæger sig i spring. Udviklingen 
går ikke kun ad »moderniseringens « forudsigelige rette vej. Der sker altså en gang imellem revolutioner dvs. kvalitative brud, fundamentale forandringer. Dette har man atter oplevet i Østeuropa og Mellemasien i årene omkring 1989. Kan det være et lærestykke for sociologen - ikke for at »lave« revolution, men for at forstå?

Hvad skete der i Østeuropa? Ud fra en konservativ synsvinkel ser det ud, som om staten, partiet og sportsorganisationen er brudt sammen ovenfra som en slags systemkrise og som trin på vejen mod at fuldende det moderne (og markedets hegemoni). Denne historie - som man ud fra overfladen har beskrevet som sportssystemets krakeleren - er ikke forkert, den mangler bare dybde. Den indeholder hverken folkets hverdagsliv eller kulturens dynamik. Der er ingen subjekter med i billedet. Revolutionen nedefra fratages opmærksomheden ved, at systemets opløsning bliver beskrevet ovenfra.

For at blive klogere er vi nødt til at bevæge os længere ned i idrættens praksis i Østeuropa og i Mellemasien. Her møder man nemlig idrættens upopularitet, som den voksede frem gennem 1970/80'erne. Man møder undertrykkelsen og genkomsten af de nationale folklorer, den vestlige modesports gennemslag, rockkulturens op$\mathrm{r} ø \mathrm{r}$, informelle ungdomsgruppers undergraven af både statsungdommen, komsomol og statssporten, den nye shamanisme i flere etniske kulturer og nye østlig-spirituelle strømninger, svarende til New Age i Vesten. Man møder nye (fornyede gamle) festkulturer, det være esternes store sangfestivaller eller tatarernes, kasachernes etc. idrætslige forårsfester ... Vi møder subjekter i bevægelse.

Eksemplerne er mangfoldige, men de er spredte. Materialerne burde samles og gennemdrøftes. Det giver imidlertid mening, at Idrættens Forskningsråd for et par år siden forhindrede et forskningsprojekt fra Idrætsforsk, som skulle dokumentere denne side af sagen. Det er ganske praktisk for den etablerede sport i Vesten ikke at lade sig genere af idrættens revolution i Øst. Så kan også sportens kontrarevolution - besættelsen af de østeuropæiske kulturer gennem den vestlige mediesport, udsalget af $\varnothing$ statleterne, genoprettelse af statsstøttet konkurrencesport etc. - gå mere gnidningsløst for sig. Og så kan man ud fra det konservative kulturkampperspektiv uskyldigt blive ved med at spørge: Revolution i Østeuropa? - Det kender jeg intet til.

Hermed er ikke sagt, at omvæltningen i den østeuropæiske idræt fuldt ud lever op til det, som vi i den vesterlandske moderne sprogbrug kalder en »revolution«. Nogle detaljer taler måske imod dette. »Revolution « er en hypotese. Den er imidlertid en velbegrundet hypotese, fordi det efterhånden er historisk dokumenteret, at idrætten - og samfundet - kan bevæge sig i spring. Den moderne gymnastiks og sportens tilblivelse omkring 1770/1820 var en revolutionær kvalitetsforandring, et spring fra en konfiguration til en anden. Og den skete i takt med en fundamental samfundsmæssig omvæltning, som bragte industrikulturen med dens produktivisme til hegemoni. Idrættens revolution omkring år 1800 er ingen romantisk-utopisk teori, men en god historie fra det virkelige liv. Og hvad der er opstået, kan også forsvinde igen.

Men som sagt, analysernes resultat kan godt være, at den østeuropæiske revolution kun blev ved overfladen, at den ikke berørte det moderne projekt, og at der ingen revolution er i idrætten. Det er imidlertid nok klogt at være forsigtig med konklusioner om konfigurationsskifte her og nu. Men uanset, om der er revolution eller ej, ét kan 
vi sige med sikkerhed: Kontrarevolutionen er åbenbart reelt tilstede.

Det er ikke nyt, at kontrarevolutionen skælder sociologer og historikere ud for, at de analyserer revolutioner. Men der er forskel på en teori om de revolutionære forandringer og en revolutionsteori, der »laver« - eller leger - revolution.

Til sidst: Om forandringer af grundlæggende art sker eller ikke sker, er ikke op til hverken den kritiske eller den konservative at bedømme. Der skal tålmodig forskning til - og kærlighed til folkets liv. Idrætten inklusive.

Kærlighed til folkets liv - uden at man ukritisk »vedkender sig « en bestemt institutionaliseringsform - hvis det er det, der er på spil, jo tak, så vil jeg gerne anklages for »grundtvigiansk romantisk bornerthed $\ll$. 